\title{
Use of indirect methodologies for determining the flow rate in water pumping systems
}

Laura Dias Ferreira ${ }^{1 *} \odot$, Adroaldo Dias Robaina ${ }^{1} \odot$, Marcia Xavier Peiter ${ }^{1} \oplus$, Jéssica Dariane Piroli1®, Silvana Antunes Rodrigues ${ }^{1} \oplus$, Chaiane Guerra da Conceição ${ }^{2} \odot$, Jhosefe Bruning ${ }^{1} \oplus$, Anderson Crestani Pereira ${ }^{1} \oplus$

\footnotetext{
1 Universidade Federal de Santa Maria, Santa Maria, RS, Brasil. E-mail: lauradiasferreira14@gmail.com; diasrobaina@gmail.com; mpeiter@gmail.com; jehpiroli@hotmail.com; rodrigues.silvana.a@gmail.com; jhosefe.b@gmail.com; acrestanipereira@gmail.com

${ }^{2}$ Instituto Federal do Rio Grande do Sul, Sertão, RS, Brasil. E-mail: chaianepg@yahoo.com.br
}

ABSTRACT: Water flow rate measurements are important for monitoring the irrigation practice. It is essential to find the real value of this variable using alternative low-cost methods which are easy to use or readily available. This study aimed to perform a comparative analysis among different methodologies for determining the flow rate in water pumping systems. Seven methodologies were analyzed, with 13 tests each. Three tests were done for adjustment and ten to test the equations. The correlation between the observed value and the values obtained by the methodologies was performed for the adjustment. The equations were subsequently used to obtain the estimated flow rate for comparison with the observed values. The comparative analysis was performed through the following statistical indicators: Precision Index, Agreement Index, Performance index, Root mean square deviation and Nash-Sutcliffe efficiency. The methodology which showed the best adjustment in the flow estimation was the U-tube vacuometer. The pressure showed the best general performance among the tested parameters with the Tensiometer, Bourdon vacuum gauge and $U$-tube vacuum gauge instruments.

\section{Uso de metodologias indiretas para a determinação da vazão em sistemas de bombeamento de água}

RESUMO: As medidas de vazão da água são importantes para o controle da prática de irrigação. É essencial conhecer o valor real desta variável usando métodos alternativos, de baixo custo, facilmente mensurados ou prontamente disponíveis. 0 objetivo do trabalho foi realizar uma análise comparativa entre diferentes metodologias para determinar a vazão em sistemas de bombeamento de água. Foram analisadas sete metodologias com treze ensaios cada. Selecionou-se três ensaios para ajustamento e dez para testar as equações. Para o ajustamento foi realizada a correlação entre o valor observado e os valores obtidos pelas metodologias. Posteriormente as equações foram utilizadas para obter as vazões estimadas, para comparação com os valores observados. A análise comparativa ocorreu por meio dos indicadores estatísticos: índice de precisão, índice de concordância, índice de desempenho, raiz quadrática do erro médio e Nash-Sutcliffe efficiency. A metodologia que apresentou melhor ajuste na estimativa da vazão foi o vacuômetro de tubo em U. Dentre os parâmetros testados, a pressão demonstrou melhor desempenho geral com os instrumentos tensiômetro, vacuômetro de Bourdon e vacuômetro de tubo em "U".

Palavras-chave: eficiência da irrigação; instrumentação; monitoramento

\footnotetext{
* Laura Dias Ferreira - E-mail: lauradiasferreira14@gmail.com (Corresponding author)

Associate Editor: Edna Maria Bonfim-Silva
} 


\section{Introduction}

Irrigation is considered an old technique to provide water supply when plants need it and in the exact amount (Tamagi et al., 2018). Furthermore, it is an essential operation in the life cycle of agriculture (Al Zayed et al., 2016).

Irrigation efficiency is an indicator for projects, water management and technologies used at several scales, being important to qualify the effective use of water and its rationalization (Wu et al., 2019). In projects which perform water management, it is common to search for techniques that aim to reduce losses and improve the efficiency in the distribution and application processes (Pimenta et al., 2018).

One of the reasons for the high cost of pumping water in irrigated areas is caused by the excess of repressed water, with the flow rate being highlighted as one of the items which define the production cost (Pérez-Urrestarazu \& Burt, 2012). Having precise information or an estimate on the flow rate is an essential factor when implementing projects which aim to achieve water rationalization and efficient management.

Amorim et al. (2017) reported that performing flow rate measurements in irrigation projects serves to control the volume of applied water. It is important to monitor water usage in detail, as it helps project designers, authorities and water owners to determine where, how often, and how much water is used or wasted (Morrison \& Friedler, 2015).

There is currently a wide variety of instruments and techniques used to measure the flow rate (Vásquez et al., 2017). The measurement of fluid flow rate may be applied for a variety of purposes, since there is a variety of high-quality meters covering different techniques (Medeiros et al., 2017). Ludwig et al. (2014) reported that determining the flow rate in irrigation systems is necessary and the methodology used for this is determinant. Thus, there are devices which measure flow rate and water consumption and provide this information on a permanent basis. However, the main obstacles to using these instruments is their high cost, the equipment requirements, the high investment for installation and the specialized labor in their use and maintenance.

An alternative to indirectly measure the flow rate and water consumption is the use of instruments based on the pressure parameter (pressure and vacuum gauges), and also water column and rotation meters (tachometers). However, there is little dissemination and a lack of information on the use of these device.

There is the need for more convenient and accurate methods to measure the water flow rate (Wang et al., 2019). Therefore, it is essential to develop research which will provide such information, since there is great concern for the efficient use of water in irrigated agriculture. It becomes increasingly more important to find the real value of this basic variable of hydrology, which is the flow rate (Maldonado et al., 2015).

Given this scenario, the objective of this work was to perform a comparative analysis among different methodologies to determine the flow rate in water pumping systems.

\section{Materials and Methods}

This study was carried out at the Laboratório de Hidráulica at the Centro de Ciências Rurais at the Universidade Federal de Santa Maria (UFSM). A water pump (WP) (Schneider, centrifugal model $B C-20 R$ ) was used with a maximum flow rate of $17 \mathrm{~m}^{3} \mathrm{~h}^{-1}$, powered by a three-phase WEG induction motor connected to a $220 \mathrm{~V}$ power grid, with nominal power of $3.7 \mathrm{~kW}(5 \mathrm{cv})$.

A closed-circuit pumping system with rigid polyvinyl chloride (PVC) brown tubes with a $40 \mathrm{~mm}$ nominal diameter was used for the water supply. A 1 1/4" diameter gate valve was installed in the pump outlet pipe, which enabled controlling and varying the flow rate. A water meter was installed after the valve to measure the actual flow of the WP, taken as standard (observed). This was a turbine water meter with a nominal flow of $20 \mathrm{~m}^{3} \mathrm{~h}^{-1}$. The volume started to be quantified from one turn and $3 / 4$ of the valve considering the displacement of the pointer.

The experiment consisted of a total of 13 test sequences, using three to adjust the functions and ten to test the equations. A random draw was performed to divide the trials. Different gradual openings were tested in the gate valve, totaling ten different opening points, with five repetitions each. Simultaneous readings all instruments used to indirectly estimate the flow rate were carried out for each opening.

The following instruments were used for the readings: a Bourdon Vacuum Gauge $(\mathrm{mmHg})$ and a U-tube vacuum gauge $(\mathrm{cmHg})$ in the suction line; an electronic metallic pressure gauge (mca), a differential pressure gauge and a mercury tensiometer on the discharge line; a water level hose coupled to the tank was used for the tank level reading; and, the motor axis rotation readings were taken by the surface speed using a MDT-2238 digital tachometer.

The direct flow rate was obtained using the water meter taken as standard $\left(\mathrm{Q}_{\mathrm{obs}}\right)$ to adjust the equations and perform the regression analysis in order to compare with the estimated flow $\left(Q_{\text {est }}\right)$ through the tested data.

The observed flow rate values were compared with the estimated values to predicting the behavior of the data. Linear regression $Y=a+b . X$ between the estimated values $(X)$ and the observed values $(Y)$ was performed to obtain the determination $\left(\mathrm{R}^{2}\right)$, angular (a) and linear (b) coefficients.

Next, the following statistical indicators were used to analyze and compare the results:

\section{Angular and linear coefficient}

Linear regression $Y=a+b . X$ was performed between the estimated values $(X)$ and the observed values $(Y)$ to obtain the correlation $\left(R^{2}\right)$, linear (b) and angular (a) coefficients.

\section{Index of precision (Ip)}

The index of precision (Ip) is a statistical measure adapted from Pearson's Correlation Coefficient which enables quantifying the degree of association between the two variables involved in the analysis (Lira \& Chaves Neto, 2006), and can be estimated by Equation 1 . 


$$
I p=\frac{\sum_{i=1}^{n}(E i-E)-(O i-O)}{\sqrt{\sum_{i=1}^{n}(E i-E)^{2} \sum_{i=1}^{n}(O i-O)^{2}}}
$$

In which - Ei are the estimated values; Oi are the observed values; $E$ is the average of the estimated values; $O$ is the average of the observed values.

\section{Index of agreement (d)}

The degree of accuracy between the variables involved was measured through the Index of agreement (d), proposed by Willmott et al. (1985). The actual flow rate values are compared with the values obtained by the different methods to verify the performance, as expressed in Equation 2.

$$
d=1-\left[\frac{\sum_{i=1}^{n}(E i-O i)^{2}}{\sum_{i=1}^{n}(|E i-O|+|O i-O|)^{2}}\right]
$$

In which - Ei is the estimated observation value; $\mathrm{Oi}$ is the measured observation value; $O$ is the average of the measured observation.

\section{Performance index (c)}

The performance index (c), proposed by Camargo \& Sentelhas (1997), was used to evaluate the performance of the flow rates obtained by indirect methods, whose value is the product out of the multiplication between the index of agreement and the index of precision, as shown in Equation 3.

$$
\mathrm{c}=\mathrm{Ic} \cdot \mathrm{Ip}
$$

The criteria for interpreting the index of precision, the index of agreement, and the performance index are performed through their respective classifications (presented in Table 1), as adapted from Pimenta et al. (2018).

\section{Root mean square deviation (RMSD)}

The RMSD, proposed by Loague \& Green (1991), indicates the data adjustment. Its values are always positive and vary from 0 to $\infty$, where values closer to zero demonstrate the best fit. It can be calculated through Equation 4.

$$
\mathrm{RMSD}=\sqrt{\frac{\sum_{\mathrm{i}=1}^{\mathrm{n}}(\mathrm{Si}-\mathrm{Oi})^{2}}{\mathrm{n}}}
$$

In which $-\mathrm{O}_{i}$ are the observed data; $\mathrm{S}_{i}$ are the estimated data; $n$ is the number of relations involved.

\section{Nash-Sutcliffe efficiency (NSE)}

The NSE, proposed by Nash \& Sutcliffe (1970), shows the alignment of the data as a function of the 1:1 straight line, whose calculation is described in Equation 5.

$$
\mathrm{NSE}=1-\left[\frac{\sum_{\mathrm{i}=1}^{\mathrm{n}}\left(\mathrm{S}_{\mathrm{i}}-\mathrm{O}_{\mathrm{i}}\right)^{2}}{\sum_{\mathrm{i}=1}^{\mathrm{n}}\left(\mathrm{O}_{\mathrm{i}}-\overline{\mathrm{O}}\right)^{2}}\right]
$$

In which - $\mathrm{O}_{\mathrm{i}}$ are the observed data; $\overline{\mathrm{O}}$ is the average of the observed data; $\mathrm{S}_{i}$ are the estimated data; $n$ is the number of relations involved.

A survey on the costs of each instrument or necessary expenses on materials for their production was conducted in order to identify the advantages and disadvantages in the different methodologies employed in relation to the economic aspects.

\section{Results and Discussion}

\section{Adjustment of equations}

It is possible to verify the confirmation of the correlation which exists between the collected and properly analyzed data through $\mathrm{Q}_{\mathrm{obs}}$ and the readings provided by the different methodologies, according to Figure 1.

Table 1. Criteria for the interpretation of the index of agreement (d), index of precision (Ip), performance index (c) and their respective classifications.

\begin{tabular}{cccc}
\hline $\begin{array}{c}\text { Index of agreement } \\
\text { (d) }\end{array}$ & $\begin{array}{c}\text { Index of precision } \\
\text { (Ip) }\end{array}$ & $\begin{array}{c}\text { Performance index } \\
\text { (c) }\end{array}$ & Classification \\
\hline $0.95-1.00$ & $0.95-1.00$ & $0.90-1.00$ & Exceptional \\
$0.89-0.95$ & $0.89-0.95$ & $0.80-0.90$ & Excellent \\
$0.84-0.89$ & $0.84-0.89$ & $0.70-0.80$ & Very good \\
$0.77-0.84$ & $0.77-0.84$ & $0.60-0.70$ & Good \\
$0.71-0.77$ & $0.71-0.77$ & $0.50-0.60$ & Moderately Good \\
$0.63-0.71$ & $0.63-0.71$ & $0.40-0.50$ & Fair \\
$0.55-0.63$ & $0.55-0.63$ & $0.30-0.40$ & Moderately Poor \\
$0.45-0.55$ & $0.45-0.55$ & $0.20-0.30$ & Poor \\
$0.32-0.45$ & $0.32-0.45$ & $0.10-0.20$ & Very poor \\
$0.00-0.32$ & $0.00-0.32$ & $0.00-0.10$ & Extremely poor \\
\hline
\end{tabular}

Source: Adapted from Pimenta et al. (2018). 

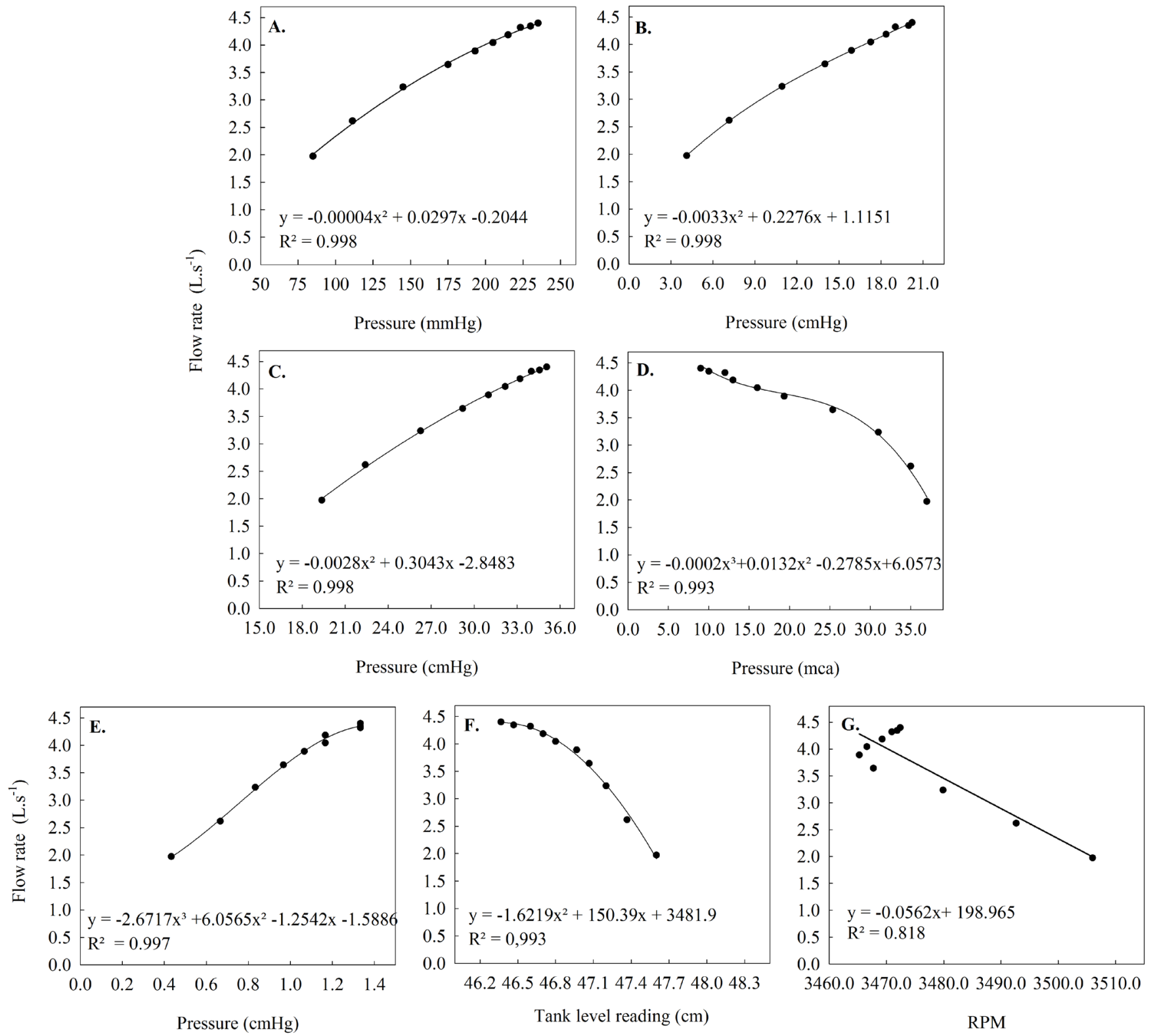

Figure 1. Correlation of the observed flow rate (water meter) in function of the values obtained by the Bourdon Vacuum gauge (A); U-tube vacuum gauge (B); Tensiometer (C); Electronic metallic pressure gauge (D); Differential pressure gauge (E); tank level reading $(F)$ and Tachometer $(G)$.

It can be seen in Figure 1 that all the methodologies used present characteristics as good indicators in the permanent flow rate monitoring, showing a good correlation with an adjustment of the equations, mostly being $2 \mathrm{nd}$ and $3 \mathrm{rd}$ degree polynomial, with coefficient of determination $\left(R^{2}\right)$ values ranging from 0.993 to 0.998 . The Tachometer (Figure 1 $\mathrm{G}$ ) was adjusted to a linear equation with $\mathrm{R}^{2}=0.818$.

It is observed that the methodologies based on the pressure parameter demonstrated a better correlation in function of the observed flow rate, visualized in Figures $1(A),(B)$ and (C) with the highest values of $R^{2}=0.998$. The Tachometer (Figure $1 \mathrm{G}$ ), despite presenting an $\mathrm{R}^{2}$ considered as acceptable according to Krause et al. (2005), was the methodology which showed the lowest correlation with the flow rate among the seven under study.

\section{Application of equations}

Figure 2 shows the relation between the values of observed $\left(Q_{\text {obs }}\right)$ and estimated $\left(Q_{\text {est }}\right)$ flow rate by the different methodologies from a linear regression analysis.

The results show that the majority of the flow rate values estimated by the different methodologies tended to overestimate the data, demonstrating higher values than the flow rate observed in the water meter, which can be visualized according to the behavior in relation to the straight line 1:1 from the axis. However, the U-tube vacuum gauge underestimated the observed values. This last result is similar to those of Andrade et al. (2007), who obtained higher flow rates measured by the water meter in relation to the values estimated by the sensors when estimating the flow rate using different electronic pressure sensors. 


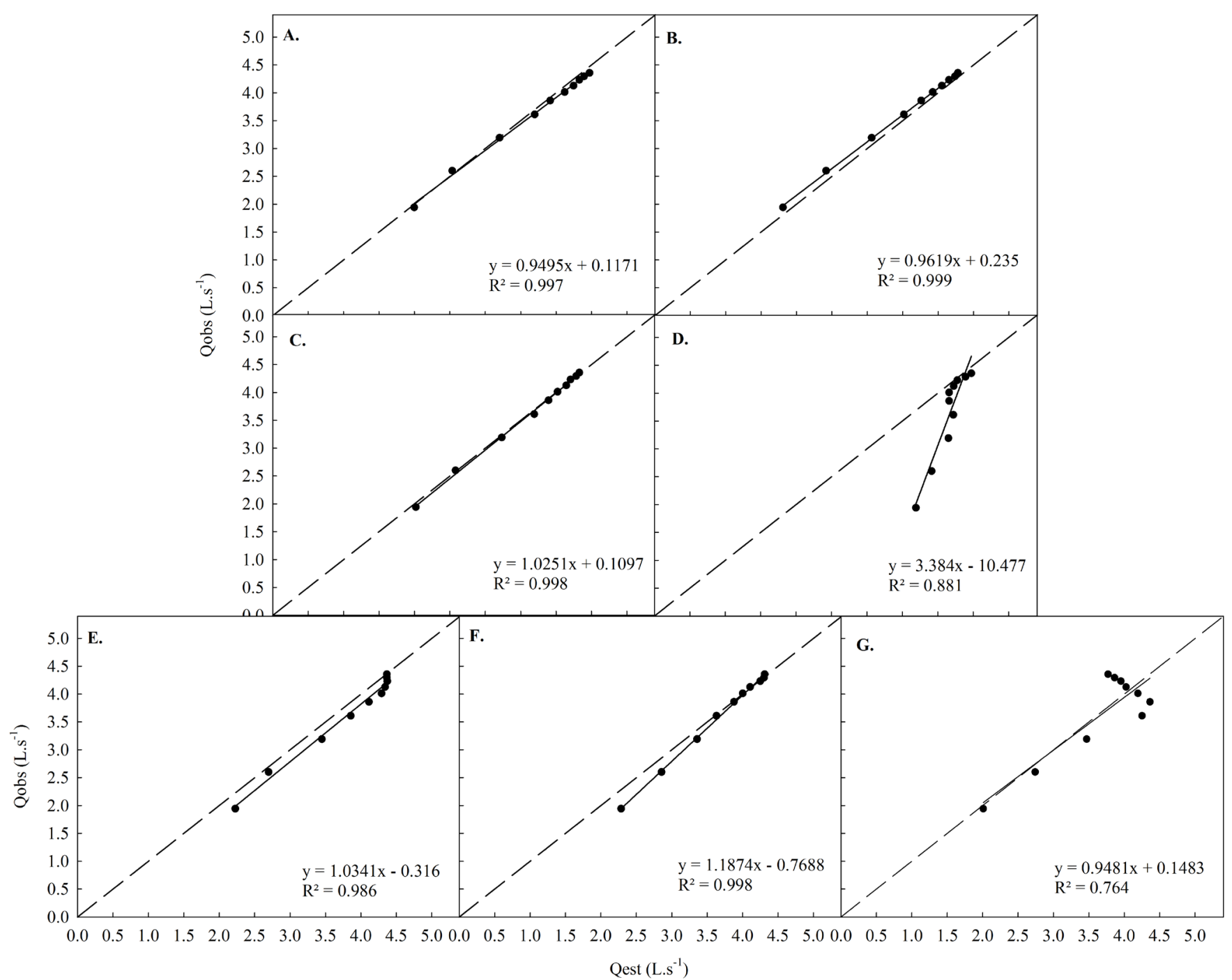

Figure 2. Observed flow rate- $Q_{\text {obs }}$ and estimated flow rate- $Q_{\text {est }}$ values for the different methodologies used; Bourdon vacuum gauge (A); U-tube vacuum gauge (B); Tensiometer (C); Electronic metallic pressure gauge (D); Differential pressure gauge (E); Tank level reading $(\mathrm{F})$ and Tachometer $(\mathrm{G})$.

It can be seen in Figure 2 that the $R^{2}$ values varied from 0.764 to 0.999 for the methodologies used, meaning there was a good fit between the data; this is in accordance with Krause et al. (2005), who consider these as acceptable intervals. This coefficient only quantifies the dispersion, and may achieve good results; however, it does not specify the difference in underestimating and overestimating the results.

It is possible to observe that the flow rate values obtained in Figure $2(A)$ and $(B)$ in relation to the suction pressure are closer to the 1:1 straight line. It can be seen in Figure 2 (C) that the values observed in the discharge pressure represent a better indicator in the flow rate monitoring, with a linear coefficient ( $a$ ) of 0.1097 and an angle coefficient $(b)$ of 1.0251 . These results are in contrast with the results of Canafístula et al. (2010), in which they obtained a better indication of flow rate monitoring using suction pressure as the monitoring tool.

Figure 2 (D) shows the worst regression performance in function of the 1:1 straight line, with values of $(a)$ and $(b)$ of 10.477 and 3.384, respectively. When compared to the others, this methodology is not recommended for determining low flow rates according to the system under study, as it demonstrates better behavior at higher flow rates, from 4.161L. $\mathrm{s}^{-1}$.

The regression behavior on the 1:1 straight line is noted in Figure $2(\mathrm{E})$ and $(\mathrm{F})$, with angular $(a)$ and linear $(b)$ coefficient values also close to zero and one, respectively. These results also demonstrate an excellent behavior of the estimated values in relation to those observed, serving as an indicator to determine the flow rate.

It is observed in Figure $2(G)$ that the estimated flow rate values presented very similar behavior to the 1:1 straight line; however, a dispersion of the points from the flow rate of $4.25{\mathrm{~L} . \mathrm{S}^{-1}}^{-1}$ is observed, demonstrating a discrepancy of the estimated values in function of those observed according to the regression analysis. This is justified because the motor pump starts to work outside its nominal rotation.

The results in this study are similar to those of Pimenta et al. (2018) in comparing two methods to measure the flow rate. These authors observed that the values demonstrated strong adherence to the regression line, indicated by the high 
coefficient of determination $\left(R^{2}\right)$, proving that the employed methodologies were adequate.

The performance evaluations of the flow rates obtained by indirect methods and their respective classifications are shown in Table 2.

It was found that the index of precision (Ip) values showed greater values than 0.9 , pointing out that there is a strong correlation between the estimated and observed data. The performance of the Bourdon's Vacuum Gauge, U-tube vacuum gauge, Tensiometer and the Tank level reading instruments was mostly "Exceptional", only varying for the electronic metallic pressure gauge and the Tachometer, which obtained a classification of "Excellent" and "Very good", respectively.

The index of agreement (d) values varied between 0.90 to 1.00 , approximately. This index shows a high agreement between the estimated and observed values, where all the device presented an "Exceptional" classification. All methodologies for the performance index (c) presented values with an "Exceptional" classification, except for the Tachometer, which presented a c $=0.872$, classified as "Excellent".

These results partially agree with Armindo et al. (2011), in which they obtained values of 0.8483 and 0.9957 for the index of agreement and 0.8456 and 0.9943 for the performance index in developing an automated flow rate measurement system with two different calibrations.

In comparing two flow rate measurement methods for PVC tubes, Pimenta et al. (2018) obtained "Excellent" classification for most of its results with high index of agreement, degree of correlation and performance index values, being similar to the results of the present study.

The RMSD for the employed methodologies showed values ranging from 0.042 to 0.789 . According to Loague \& Green (1991), the values for this indicator vary from 0 to $\infty$, and the closer to 0 , the better the data adjustment. Thus, we can observe that the three best adjustments were obtained with the Tensiometer, the Bourdon vacuum gauge and the $U$-tube vacuum gauge, presenting values closer to 0 when compared to the other methodologies. The methodology which showed the least adjustment was the electronic metallic manometer, followed by the tachometer, with RMSD values equal to 0.789 and 0.376 , respectively.

According to Silva et al. (2018), the NSE represents the data alignment in relation to the $1: 1$ dispersion graph, demonstrating its behavior and performance. This indicator ranged from 0.954 to 0.999 for the methodologies, with the highest values of 0.999 for the Bourdon vacuum gauge, the U-tube vacuum gauge and the Tensiometer. Moriasi et al.
(2007) reported that the values of this indicator vary from $-\infty$ to 1.0 , where between 0 to 1.0 classifies the performance as acceptable, and 1.0 the optimal value. This demonstrates that the aforementioned methodologies showed the best alignment for the 1:1 straight line and very good performance when compared to the others.

Based on this study, the importance of having instruments which are well calibrated and present reliability in their results to measure the flow rate is apparent. Hassanli et al. (2012) argues that the correct operation and installation of flow rate meters should be part of the commissioning processes, checking and calibrating this equipment to meet the flow conditions, thereby helping in the practice of sustainable water management.

A cost survey was also performed as one of the purposes of this study to calculate the expenses in acquiring or manufacturing the instruments used, shown in Table 3.

It is possible to observe that some instruments generally have a significant initial cost, which could become a disadvantage for the consumer to acquire them.

The companies which provide technical assistance who perform flow rate measurements in water pumping systems do not provide a form of permanent monitoring to the consumer. In this sense, there is a need to provide regular technical assistance to the consumer every time they want to determine the flow rate. Thus, there is generally a high cost for this service. When companies have their own equipment for sale, one that estimates and monitors the fluid, it has a high cost, making it mostly unfeasible for the consumer, especially for small producers.

Despite the initial cost for most of these devices under study, there would be no periodic need for new assistance to estimate the flow rate, because the producer would then have their own equipment, being able to estimate the flow rate of their irrigation system. In addition, the producer will

Table 3. Cost to acquire or build the instruments used to determine the flow rate.

\begin{tabular}{cc}
\hline Instrument & Cost (R\$) \\
\hline Bourdon vacuum gauge & 120.00 \\
U-tube vacuum gauge & 750.00 \\
Electronic metallic pressure gauge & $1,000.00$ \\
Tensiometer & 750.00 \\
Differential pressure gauge & 850.00 \\
Tank level reading & 50.00 \\
Tachometer & 500.00 \\
\hline
\end{tabular}

Table 2. Statistical indicators and classification for the different methodologies.

\begin{tabular}{ccccccc}
\hline Instruments & RMSD & NSE & Ip & d & c & Classification \\
\hline Bourdon vacuum gauge & 0.088 & 0.999 & 0.998 & 0.999 & 0.998 & Excellent \\
U-tube vacuum gaug & 0.106 & 0.999 & 0.999 & 0.999 & 0.999 & Excellent \\
Electronic metallic pressure gauge & 0.789 & 0.954 & 0.938 & 0.989 & 0.928 & Optimum \\
Tensiometer & 0.042 & 0.999 & 0.999 & 1.000 & 0.999 & Excellent \\
Differential pressure gauge & 0.208 & 0.996 & 0.993 & 0.999 & 0.992 & Excellent \\
Tank level reading & 0.146 & 0.998 & 0.999 & 0.999 & 0.998 & Excellent \\
Tachometer & 0.376 & 0.980 & 0.874 & 0.997 & 0.872 & Excellent \\
\hline
\end{tabular}

Source: the author. 
only require a new technical assistance visit in case a piece of equipment needs maintenance.

Regarding costs, it should be noted that the electronic metallic pressure gauge proved to be one of the instruments with the lowest performance and presents the highest cost $(R \$ 1,000.00)$ in comparison to the others. The instruments which showed the best overall performance in estimating the flow rate were the Tensiometer, the Bourdon Vacuum Gauge and the U-tube Vacuum Gauge.

Moreover, it is noted that in addition to presenting the best general performance, the instruments mentioned above have acquisition values ranging from $R \$ 120.00$ to $R \$ 750.00$, which is considered low cost in relation to the others. Thus, the cost becomes viable compared to the ultrasonic meter, which is more commonly used in water irrigation pumping systems. According to Duda (2019), the ultrasonic meter has a high acquisition cost for tubes with small diameters and may vary according to its specifications.

Therefore, depending on its performance and cost, the product becomes viable for the final consumer. When building a simple and low-cost pressure gauge, Figueredo Júnior et al. (2006) found that the replacement of equipment with high cost and difficult maintenance can be performed without causing damage.

There is a wide variety of flow rate meters on the market, and their use depends on the application needs and characteristics; however, there is an absence of these meters in the management of water systems, which is a consequence of high acquisition costs as well as installation difficulties and maintenance (Siqueira \& Souza, 2020).

\section{Conclusions}

Considering the methodologies used to determine the water flow rate in pumping systems, it can be concluded that:

The flow rate can be determined indirectly through the generated graphs and equations. The methodologies which showed the best overall performance and a high degree of accuracy in estimating the flow rate were the Tensiometer, Bourdon's Vacuum Gauge and the U-tube vacuum gauge, respectively.

The pressure parameter presented the best result for permanent flow rate monitoring, considering the adopted pump and system under study. It can be used in both the entrance and in the outlet of the system.

The methodologies present low acquisition cost which benefits installing this equipment on farms, thereby enabling to determine the flow rate.

\section{Acknowledgments}

This paper was written with the support of the Conselho Nacional de Desenvolvimento Científico e Tecnológico (CNPq), through the granting of a scholarship.

\section{Compliance with Ethical Standards}

Author contributions: Conceptualization: LDF, ADR, MXP; Data curation: LDF; Formal analysis: LDF, JDP, SAR, CGC, JB, $A C P$; Funding acquisition: LDF, ADR, MXP; Investigation; LDF, JDP, SAR, CGC, JB, ACP; Methodology: LDF, ADR, MXP; Project administration: LDF, ADR, MXP; Resources: LDF, JDP, SAR, JB, ACP; Supervision: ADR, MXP; Validation: LDF, ADR, MXP; Visualization: LDF; Writing - original draft: LDF, SAR, CGC, JB; Writing - review \& editing: LDF; ADR, MXP, SAR, JB

Conflict of interest: We declare that there are no conflicts of interest.

Funding: Conselho Nacional de Desenvolvimento Científico e Tecnológico (CNPq).

\section{Literature Cited}

Al Zayed, I.S.; Elagib, N.A.; Ribbe, L.; Heinrich, J. Satellite-based evapotranspiration over Gezira Irrigation Scheme, Sudan: A comparative study. Agricultural Water Management, v.177, n.1, p.66-76, 2016. https://doi.org/10.1016/j.agwat.2016.06.027.

Amorim, E.L.; Pereira, M.S.; Melo, E.A. De. Fortes, F.C.A.; Souza, K.L.J.L. de. Equação da continuidade aplicada ao cálculo de vazão do igarapé São Lourenço do Município de Cantá. Revista Multidisciplinar Pey Këyo Científico, v.2, n.2, p.1-13, 2017. http://periodicos.estacio.br/index.php/pkcroraima/article/ view/3827/1650. 29 Mar. 2020.

Andrade, C.L.T.; Perroni, B.L.T.; Albuquerque, P.E.P.; Oliveira, G.R.; Pruski, F.F.; Gonçalves, F.A. Desenvolvimento e avaliação de dispositivos de controle de vazão derivada em canais de irrigação. Irriga, v.12, n.4, p.439-445, 2007. https://doi.org/10.15809/ irriga.2007v12n4p439-45.

Armindo, R.A.; de Queiroz, T. M.; Botrel, T.A., Garzella, T.C. Desenvolvimento e avaliação de um sistema automatizado de aquisição de dados para medição de vazão," Auto-Venturi". Bioscience Journal, v.27, n.5, p. 764-774, 2011. http://www.seer. ufu.br/index.php/biosciencejournal/article/view/11745/7890. 03 Mar. 2020.

Camargo, A.P.; Sentelhas, P.C. Avaliação do desempenho de diferentes métodos de estimativa da evapotranspiração potencial no estado de São Paulo, Brasil. Revista Brasileira de Agrometeorologia, v.5, n.1, p.89-97, 1997. http://www.sbagro.org/files/biblioteca/124. pdf. 30 Mar. 2020.

Canafístula, F.J.F.; Lopes, F.B.; Soares, R.B.; Andrade, E.M.; Teixeira, A.S. Investigação de variável adequada ao controle automático de vazão sem uso de sensores em campos irrigados por meio de análise multivariada. Ciência Rural, v.40, n.11, p.2317-2323, 2010. https://doi.org/10.1590/S0103-84782010001100011.

Duda, Stephen W. Selecting and specifying pipe flow meters. ASHRAE Journal, v.61, n.9, p. 62-68, 2019.

Figueredo Júnior, L.G. M.; Dias, N.S; Duenhas, L.H.; Botrel, T.A. Construção e calibração de um manômetro de leituras digital microprocessado. Revista Irriga, v. 11, n. 4, p. 492-499, 2006. https://doi.org/10.15809/irriga.2006v11n4p492-499. 
Hassanli, A.M.; Pezzantti, D.; Cape, J. In Situ Verification Technologies of Flow Meters for Sustainable Water Management. Irrigation and Drainage, v. 61, n. 4, p. 520-526, 2012. https://doi.org/10.1002/ ird.690.

Krause, P.; Boyle, D.P.; Base, F. Comparison of different efficiency criteria for hydrological model assessment. Advances in Geosciences v.5, n.1, p.89-97, 2005. https://doi.org/10.5194/ adgeo-5-89-2005.

Lira, S.A.; Chaves Neto, A. Coeficientes de correlação para variáveis ordinais e dicotômicas derivados do coeficiente linear de Pearson. Revista Ciência \& Engenharia, v.15, n.1-2, p.45-53, 2006.

Loague, K.; Green, R.E. Statistical and Graphical Methods for Evaluating Solute Transport Models: Overview and Application. Journal of Contaminant Hydrology, v.7, n.1-2, p.51-73, 1991. https://doi.org/10.1016/0169-7722(91)90038-3.

Ludwig, R.; Silva, D.M.; Damé, R.C.F.; Teixeira, C.F.A. Comparação entre metodologias para estimativa de vazão em canal de irrigação no arroio Chasqueiro/RS. Irriga, v.19, n.1, p.94-102, 2014. https://doi.org/10.15809/irriga.2014v19n1p94.

Maldonado, L.H.; Wendland, E.C.; Porto, R. de M. Avaliação de métodos de baixo custo para medição de vazão em córregos. Rev. Ambiente \& Água, v.10, n.2, p.402-412, 2015. https://doi. org/10.4136/ambi-agua.1293.

Medeiros, K.A.R.; Barbosa, C.R.H.; De Oliveira, E.C. Non-intrusive method for measuring water flow rate in pipe. Periódico Tche Quimica, v.14, n.27, p.44-50, 2017. http://www.deboni.he.com. br/Periodico27.pdf. 19 Mar. 2020.

Moriasi, D.; Arnold, J.G.; Van Liew, M.W.; Bingner, R.L.; Harmel, R.D.; Veith, T.L. Model evaluation guidelines for systematic quantification of accuracy in watershed simulations. Transactions of the ASABE, v.50, n.3, p.885-900, 2007. https://doi. org/10.13031/2013.23153.

Morrison, J.; Friedler, E.A critical review of methods used to obtain flow patterns and volumes of individual domestic water using appliances. Urban Water Journal, v. 12, n.4, p.328-343, 2015. https://doi.org/10.1080/1573062X.2014.900090.

Nash, J.E.; Sutcliffe, J.V. River flow forecasting through conceptual models part I - A discussion of principles. Journal of Hydrology, v.10, n.3, p.282-290, 1970. https://doi.org/10.1016/00221694(70)90255-6.
Pérez-Urrestarazu, L.P.; Burt, C.M. Characterization of pumps for irrigation in central California: Potential energy savings. Journal of Irrigation and Drainage Engineering, v.138, n.9, p.815-822, 2012. https://doi.org/10.1061/(ASCE)IR.1943-4774.0000463.

Pimenta, B.D.; Robaina, A.D.; Peiter, M.X.; Kirchner, J.H.; Mezzomo, W.; Torres, R.R. Desempenho do medidor ultrassônico de vazão em diferentes tubos de policloreto de vinila. Irriga, v.23, n.1, p.87-95, 2018. https://doi.org/10.15809/irriga.2018v23n1p87.

Silva, V.P.R.; Silva, R.A.; Maciel, G.F.; Braga, C.C.; Júnior, J.L.C.S.; Souza, E.P.; Almeida, R.S.R.; Silva, M.T.; Holanda, R.M. Calibration and validations of the AquaCrop model for the soybean crop grow under diferente levels of irrigation in the Motopiba region, Brazil. Revista Ciência Rural, v.48, n.1, p.1-8, 2018. https://doi. org/10.1590/0103-8478cr20161118.

Siqueira, N.A.; Souza, P.A de. Medidor prismático hexagonal: uma alternativa à macromedição. Engenharia Sanitaria e Ambiental, v. 25 , n. 5 , p. $649-653,2020$. https://doi.org/10.1590/s141341522020192106

Tamagi, J.T.; Uribe-Opazo, M.A.; Boas, M.A.V.; Johann, J.A.; Guedes, L.P.C. Spatial variability of the water depth applied by fixed sprinkler irrigation systems. Engenharia Agrícola, v.38, n.2, p. 188-196, 2018. https://doi.org/10.1590/1809-4430-eng.agric. v38n2p188-196/2018.

Vásquez, J.D.H.; Orlando, A.F.; Frota, M.N.; Oliveira, E.C. An alternative gravimetric measurement standard for calibration of liquid flow meters. Flow Measurement and Instrumentation, v.58, n.1, p.8796, 2017. https://doi.org/10.1016/j.flowmeasinst.2017.09.016.

Wang, Z.; Angiroglu, E.; Wang, G.; Song, L. Accuracy improvement of virtual pump water flow meters using calibrated characteristics curves at various frequencies. Energy and Buildings, v.191, n.1, p.143-150, 2019. https://doi.org/10.1016/j.enbuild.2019.03.021.

Wilmott, C.J.; Ackleson, S.G.; Davis, R E.; Feddema, J.J.; Klink, K.M.; Legates, D.R.; O’Donnell, J.; Rowe, C.M. Statistics for the evaluation and comparison of models. Journal of Geophysical Research, Ottawa, v.90, n.C5, p.8995-9005, 1985. https://doi. org/10.1029/JC090iC05p08995.

$\mathrm{Wu}, \mathrm{D}$; Cui, Y; Luo, Y. Irrigation efficiency and water-saving potential considering reuse of return flow. Agricultural Water Management, v.221, n.1, p.519-527, 2019. https://doi.org/10.1016/j. agwat.2019.05.021. 